AGRICULTURE AND BIOLOGY JOURNAL OF NORTH AMERICA

ISSN Print: 2151-7517, ISSN Online: 2151-7525, doi:10.5251/abjna.2011.2.7.1108.1112

(C) 2011, ScienceHuß, http://www.scihub.org/ABJNA

\title{
Response of olive seedlings to foliar sprays with amino acids and some micro elements
}

\author{
${ }^{1}$ Aml, R.M. Yousef; ${ }^{2}$ E.A.M. Mostafa and ${ }^{2}$ M.M.S. Saleh \\ ${ }^{1}$ Horticultural Crops Technology, National Research Center, Cairo, Egypt \\ ${ }^{2}$ Pomology Department, National Research Center, Cairo, Egypt \\ Corresponding author: M.M.S. Saleh: e-mail: mmsssa2000@yahoo.com
}

\begin{abstract}
Kronaki olive seedlings were sprayed with Pepton (the commercial form of amino acids mixture) at 0.5 and $1 \%$ alone or in combination with mixture of some chelated micro elements $(\mathrm{Zn}+\mathrm{Mn}+$ $\mathrm{Fe}$ ) at 0.25 and $0.5 \%$. Each treatment was sprayed three times through the growing seasons. The obtained results indicated that, treatment No. 4 (Pepton $0.5 \%+$ micro elements at $0.25 \%$ ) was the most effective one comparing with the other treatments. Since this treatments gave the best results concerning height and diameter of the plant, branches number, leaves number and leaves area comparing with the control.
\end{abstract}

Key words: Kronaki olive seedlings, amino acids, micro elements.

\section{INTRODUCTION}

Olive tree (Olea europaea L.) is one of the most important fruit crops grown in the newly reclaimed area in Egypt. Although olive trees can survive and grow under low soil fertility and water availability conditions. Many research studies have been indicating that improving soil fertility and satisfying water requirement are essential factors to obtain a high production. An appropriate fertilization is important during the first years of growth when the tree has to take in nutrients and produce assimilates for the development of its root system canopy perennial structures and to prepare itself for future fructification. In this period, an adequate nutrition stimulates a fast vegetative growth which presumably reduces the juvenile and non productive phase (Garcia et al., 1999). Amino acids as organic nitrogenous compounds are the building blocks in the synthesis of proteins, which are formed by a process in which ribosomes catalyze the polymerization of amino acids, Davies (1982). Several hypotheses have been proposed to explain the role of amino acids in plant growth. Available evidence suggests several alternative routes of IAA synthesis in plants starting from amino acids, Hashimoto and Yamada (1944). In this respect, Waller and Nowaki (1978) suggested that the regulatory effects of certain amino acids like phenylalanine and ornithine on plant development is through their influence on gibberellins. Mode of action for micro-elements was explained by Larve and Johnson (1989) where iron (Fe) complexes with proteins to from important enzymes in the plant and is associated with chloroplasts, where it has some roles in the synthesizing chlorophyll. Zinc has been identified as component of almost 60 enzymes, therefore, it has a role in many plant functions and it has a role as an enzyme in producing the growth hormone IAA. Manganese $(\mathrm{Mn})$ participates in several important processes including photosynthesis and metabolism of both nitrogen and carbohydrate. On the other hand, foliar fertilizers as chelated should be easily absorbed by the plants, rapidly transported, and should be easily release their ions to affect the plant Larue and Johnson (1989). Amino acids have a chelating effect on micronutrients when applied together, the absorption and transportation of micronutrients inside the plant is easier, this effect is due to the chelating action, the effect of cell membrane permeability and low molecular weight, Westwood (1993).

Accordingly, this study was aimed to evaluate the effect of spraying some chelated microelements (Fe, $\mathrm{Zn}$ and $\mathrm{Mn}$ ) and amino acids on growth of Karonaki olive seedlings. 
Table (1). Some physical and chemical properties of the experimental soil.

\begin{tabular}{|c|c|c|c|c|c|c|c|c|c|c|c|c|c|c|}
\hline \multirow{2}{*}{\multicolumn{3}{|c|}{$\begin{array}{c}\text { Particle size } \\
\text { distribution (\%) }\end{array}$}} & Texture & Ec & \multirow{2}{*}{$\mathrm{pH}$} & \multicolumn{5}{|c|}{ Available nutrients } & \multicolumn{4}{|c|}{ Available nutrients } \\
\hline & & & soil & ${ }_{1}^{d_{s} m^{-}}$ & & \multicolumn{5}{|c|}{ (Cation) } & \multicolumn{4}{|c|}{ (Anion) } \\
\hline \multirow[t]{2}{*}{ Sand } & \multirow[t]{2}{*}{ Silt } & \multirow[t]{2}{*}{ Clay } & \multirow[t]{2}{*}{ sandy } & \multirow[t]{2}{*}{1.5} & \multirow[t]{2}{*}{8.2} & \multirow[t]{2}{*}{$\mathrm{N} \%$} & \multirow[t]{2}{*}{ P \% } & \multirow[t]{2}{*}{$\mathrm{K} \%$} & \multirow{2}{*}{$\begin{array}{c}\mathrm{Ca} \\
\mathrm{meg} / \mathrm{l}\end{array}$} & \multirow{2}{*}{$\underset{\mathrm{meg} / \mathrm{l}}{\mathrm{Mg}}$} & \multirow[t]{2}{*}{$\mathrm{CO} 3$} & $\begin{array}{c}\mathrm{HCO} \\
3 \\
\end{array}$ & \multirow[t]{2}{*}{$\begin{array}{l}\mathrm{Cl} \\
-\end{array}$} & \multirow[t]{2}{*}{ SO4 } \\
\hline & & & & & & & & & & & & $\mathrm{meg} / \mathrm{l}$ & & \\
\hline 90 & 5 & 5 & & & & trace & 0.44 & 0.57 & 2.65 & 2.4 & - & 3.85 & 53 & 55.65 \\
\hline
\end{tabular}

\section{MATERIAL AND METHODS}

This study was carried out through two successive seasons (2008 and 2009) on two years old Kronaki olive seedlings planted in the experimental station of National Research Center, at Al-Nobaria district, AlBehera governorate, Egypt. The soil physical and chemical properties are shown in Table 1.

The following materials were sprayed three times at March, July and September on the seedlings:

- Pepton [(the commercial product of amino acid (AA)] at 0.5 and $1 \%$.

- Mixture of micro elements (ME) at 0.25 and $1 \%$ as follows:

- $\quad$ Chelated iron = Fe EDTA $(6 \%)$

- $\quad$ Chelated zinc $=$ Zn EDTA $(12 \%$ Zn $)$.

- Chelated manganese = MN EDTA $(14 \%$ $\mathrm{MN}$ ).

Amino acids (AA) at form of pepton $85 / 16$ as commercial product which contains of 18 mixed amino acids. The total percent of amino acids in the product is $85 \%$ [ $(16 \%$ as free amino acids in L- $\alpha$ type $)$ $+12 \%$ organic nitrogen $+3.5 \%$ potassium oxide].

The seven treatments involved this study can be arranged as follows:

1- Control.

2- Amino acids at $0.5 \%$.

3- Amino acids at $1 \%$.

4- Amino acids at $0.5 \%+$ micro elements at $0.25 \%$.

5- Amino acids at $0.5 \%+$ micro elements at $0.5 \%$.

6- Amino acids at $1 \%+$ micro elements at $0.25 \%$.

7- Amino acids at $1 \%+$ micro elements at $0.5 \%$.

All seedlings received the same agricultural practices.
At the end of the growing season (mid December of each season) the following determinations were recorded for all seedlings:

- Plant height $(\mathrm{cm})$.

- Stem diameter (cm).

- Number of branches.

- Number of total leaves.

- Total leaves area $\left(\mathrm{cm}^{2}\right)$.

Leaf samples were collected from each seedling to determine $\mathrm{N}, \mathrm{P}, \mathrm{K}, \mathrm{Zn}, \mathrm{Mn}$ and $\mathrm{Fe}$ contents according to the methods described by Cotteine et al. (1982).

Statistical analysis: the design for this experiment was completely randomized design with three replications. Data were subjected to analysis of variance and Duncan's multiple test was used to differentiate means (Duncan, 1955).

\section{RESULTS AND DISCUSSION}

Vegetative growth: Results in Tables 2 and 3 clearly showed that, most treatments had a positive effect on plant height when compared with the control. In this respect, spraying Kronaki olive seedlings with amino acids at $0.5 \%+$ micro elements at $0.25 \%$ recorded the tallest plants in both studied seasons, since it recorded 93.3 and $96.3 \mathrm{~cm}$ in the first and second seasons, respectively.

In case of stem diameter, foliar sprays with amino acids alone or in combination with micro elements mixture gave higher values for stem diameter in both studied seasons. In this concern, treatment No. 4 (amino acids at $0.5 \%+$ micro elements at $0.25 \%$ ) recorded the higher values for stem diameter in the two seasons, since it recorded 0.70 and $0.69 \mathrm{~cm}$ in the first and second seasons, respectively.

Regarding number of branches per seedling in the first season, it is observed that treatment No. 
4 showed the highest number of branches followed by treatment No. 5 without significant differences. However, the control treatment gave the lowest number of branches per seedling during the two seasons, since it recorded 7.33 and 7.67 in the first and second seasons, respectively.

Concerning number of the leaves per seedling, data in the Table 2 and 3 showed that the highest value was obtained by treatment No.4 (amino acids at $0.5 \%+$ micro elements at $0.25 \%$ ) in both studied seasons, since this treatment recorded 132 and 124 leaves in the first and second seasons, respectively. The control treatment recorded the least value of leaves number per seedling during the two seasons, where it recorded 37.67 and 44.0 leaves in the first and second seasons, respectively.

Leaves area recorded the highest value when seedlings sprayed with amino acids at $0.5 \%+$ micro elements at $0.25 \%$ (treatment No. 4), since it was 132 and $124 \mathrm{~cm}^{2}$ in the first and second seasons, respectively.

Table (2): Physical properties of Kronaki olive seedlings as affected by different foliar treatments at First Season

\begin{tabular}{|c|c|c|c|c|c|c|}
\hline Treatments Characters & $\begin{array}{c}\text { Plant } \\
\text { height }(\mathrm{cm})\end{array}$ & $\begin{array}{c}\text { Plant } \\
\text { diameter(cm) }\end{array}$ & $\begin{array}{l}\text { Branches } \\
\text { numbers }\end{array}$ & $\begin{array}{c}\text { Leaves } \\
\text { numbers }\end{array}$ & $\begin{array}{l}\text { Leaves } \\
\text { area }\left(\mathrm{cm}^{2}\right)\end{array}$ & $\begin{array}{c}\text { Total } \\
\text { area }\left(\mathrm{cm}^{2}\right)\end{array}$ \\
\hline Control & $75.00 \mathrm{ab}$ & $0.61 \mathrm{a}$ & $7.67 \mathrm{a}$ & $61.00 \mathrm{bc}$ & $7.03 \mathrm{a}$ & $428.8 \mathrm{~cd}$ \\
\hline Pepton $0.5 \%$ & $65.67 \mathrm{~b}$ & $0.64 a$ & $10.33 a$ & $44.00 \mathrm{c}$ & $7.33 \mathrm{a}$ & $322.6 \mathrm{~d}$ \\
\hline Pepton 1\% & $68.67 \mathrm{ab}$ & $0.54 \mathrm{a}$ & $8.00 \mathrm{a}$ & $107.0 \mathrm{ab}$ & $7.90 \mathrm{a}$ & $846.1 \mathrm{abc}$ \\
\hline $\begin{array}{l}\text { Pepton } 0.5 \%+\text { micro } \\
\text { elements } 0.25 \%\end{array}$ & 96.33 a & $0.69 a$ & $11.33 \mathrm{a}$ & $124.00 \mathrm{a}$ & $7.65 \mathrm{a}$ & 949.0 a \\
\hline $\begin{array}{l}\text { Pepton } 0.5 \%+\text { micro } \\
\text { elements } 0.5 \%\end{array}$ & $81.67 \mathrm{ab}$ & $0.65 a$ & $13.00 \mathrm{a}$ & $123.33 \mathrm{a}$ & $7.34 \mathrm{a}$ & $905.9 \mathrm{ab}$ \\
\hline $\begin{array}{l}\text { Pepton } 1 \%+\text { micro elements } \\
0.25 \%\end{array}$ & $79.33 a b$ & 0.78 a & $3.67 \mathrm{a}$ & $69.00 \mathrm{bc}$ & $6.91 \mathrm{a}$ & $477.1 \mathrm{~cd}$ \\
\hline $\begin{array}{l}\text { Pepton } 1 \%+\text { micro elements } \\
0.5 \%\end{array}$ & $78.00 \mathrm{ab}$ & $0.58 \mathrm{a}$ & $12.00 \mathrm{a}$ & $104.67 \mathrm{ab}$ & $4.89 \mathrm{~b}$ & $512.6 \mathrm{bcd}$ \\
\hline
\end{tabular}

Table (3): Physical properties of Kronaki olive seedlings as affected by different foliar treatments at second Season

\begin{tabular}{|l|c|c|c|c|c|c|}
\hline $\begin{array}{l}\text { Treatments } \\
\text { Characters }\end{array}$ & $\begin{array}{c}\text { Plant } \\
\text { height }(\mathrm{cm})\end{array}$ & $\begin{array}{c}\text { Plant } \\
\text { diameter(cm) }\end{array}$ & $\begin{array}{c}\text { Branches } \\
\text { numbers }\end{array}$ & $\begin{array}{c}\text { Leaves } \\
\text { numbers }\end{array}$ & $\begin{array}{c}\text { Leaves } \\
\text { area } \\
\left(\mathrm{cm}^{2}\right)\end{array}$ & $\begin{array}{c}\text { Total } \\
\text { area }\left(\mathrm{cm}^{2}\right)\end{array}$ \\
\hline Control & $75.33 \mathrm{a}$ & $0.61 \mathrm{a}$ & $7.33 \mathrm{ab}$ & $63.00 \mathrm{bc}$ & $7.43 \mathrm{a}$ & $458.3 \mathrm{~cd}$ \\
\hline Pepton 0.5\% & $65.33 \mathrm{a}$ & $0.65 \mathrm{a}$ & $9.33 \mathrm{ab}$ & $37.67 .00 \mathrm{c}$ & $7.74 \mathrm{a}$ & $368.3 \mathrm{~d}$ \\
\hline Pepton 1\% & $69.00 \mathrm{a}$ & $0.53 \mathrm{a}$ & $7.33 \mathrm{ab}$ & $106.0 \mathrm{ab}$ & $8.41 \mathrm{a}$ & $876.4 \mathrm{ab}$ \\
\hline $\begin{array}{l}\text { Pepton 0.5\%+micro elements } \\
0.25 \%\end{array}$ & $93.33 \mathrm{a}$ & $0.7 \mathrm{a}$ & $13.00 \mathrm{a}$ & $132.0 \mathrm{a}$ & $8.04 \mathrm{a}$ & $109.9 \mathrm{a}$ \\
\hline $\begin{array}{l}\text { Pepton 0.5\%+ micro elements } \\
0.5 \%\end{array}$ & $74.00 \mathrm{a}$ & $0.63 \mathrm{a}$ & $12.00 \mathrm{a}$ & $110.0 \mathrm{a}$ & $7.76 \mathrm{a}$ & $685.4 \mathrm{bc}$ \\
\hline $\begin{array}{l}\text { Pepton 1\%+ micro elements } \\
0.25 \%\end{array}$ & $67.67 \mathrm{a}$ & $0.62 \mathrm{a}$ & $2.33 \mathrm{~b}$ & $51.33 \mathrm{c}$ & $7.35 \mathrm{a}$ & $377.3 \mathrm{~d}$ \\
\hline $\begin{array}{l}\text { Pepton } 1 \%+\text { micro elements } \\
0.5 \%\end{array}$ & $78.67 \mathrm{a}$ & $0.57 \mathrm{a}$ & $10.33 \mathrm{a}$ & $101.33 \mathrm{ab}$ & $5.38 \mathrm{~b}$ & $544.3 \mathrm{~cd}$ \\
\hline
\end{tabular}




\section{Leaf mineral content:}

1- Macro elements:

Data in Fig (1) shows that nitrogen content in the leaves was significantly increased by all treatments as compared to the control. In this respect, foliar sprays with amino acids at $1 \%$ (treatment No.3) recorded the highest $\mathrm{N}$ value $(1.28 \%)$ followed by treatments No. 7 ,
6 and 5 , since they recorded $1.25,1.20$ and $1.19 \%$, respectively.

Regarding phosphorus content in the leaves, results in Fig 1 indicated that no significant differences were detected among all treatments. However, phosphorus percentage ranged between (0.1- 0.9\%).

Potassium content in the leaves was slightly increased by treatment No.4 followed by treatment No. 6 , since they recorded 0.82 and $0.81 \%$, respectively.

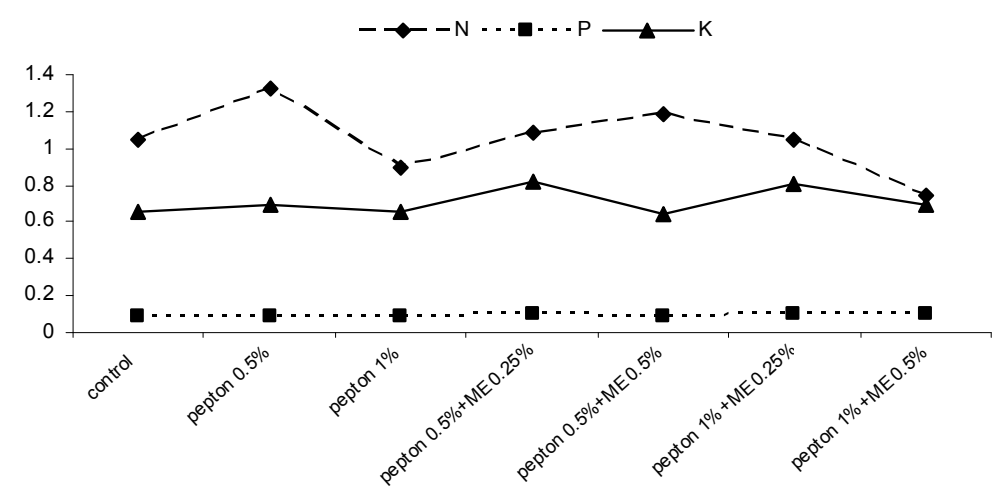

Fig (1): Macro elements in leaves of Kronaki olive seedling as affected by different foliar treatments during the two studied seasons

2- Micro elements:

However, treatment No. 6 exhibited the

Data in Fig (2) showed that, treatment No. 6 and 7 recorded higher values of Fe content as compared with the other treatments. significantly greatest leaf Fe content $(774.8$ ppm) followed by treatment No.7 (965.0 ppm).

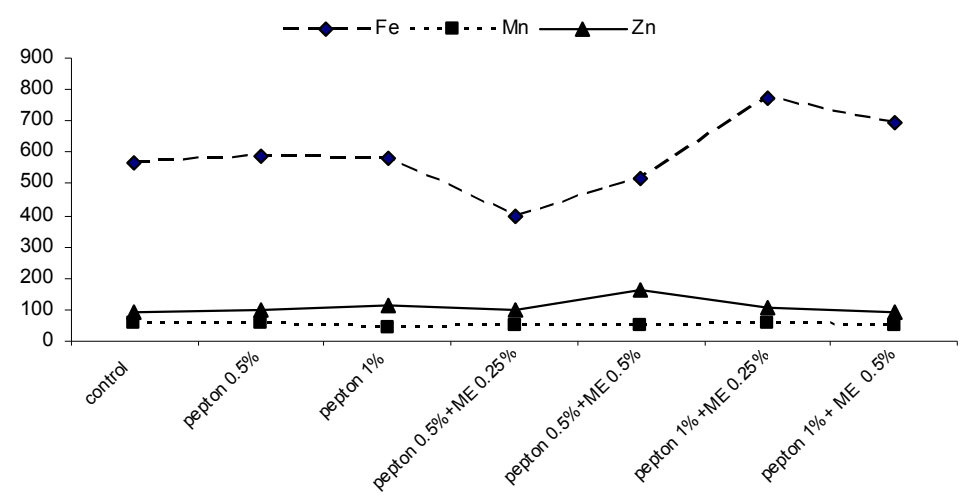

Fig (2): Trace elements in leaves of Kronaki olive seedling affected by different foliar treatments during the two studied seasons

As for manganese content, results indicated that no significant differences were detected in the leaves among different treatments. In this respect, $\mathrm{Mn}$ ranged between $45.42-55.4$ ppm in the leaves. 
Regarding zinc content in the leaves, data in Fig 2 cleared that this element was significantly affected by treatment No. 5 (amino acids at $0.5 \%+$ micro elements at $.05 \%$ ) as compared with the other treatments.

The previous results could be explained according to Ghanta and Metra (1993), who reported that, improving growth characters in response to the foliar application of micronutrients, may be due to their positive action on increasing cell division in the meristematic tissues and accelerating carbohydrates and proteins formation. Also, these elements play an important role in the multi-biological processes such as the role of $\mathrm{Zn}$ in the synthesis of IAA (Nijjar, 1985). On the other side, the effect of amino acids may be explained due to Waller and Nowaki (1978) who suggested the regulatory effects of certain amino acids like phenylalanine and ornithine, on plant development is through their influence on gibberellins. In this respect, Hashimoto and Yamada (1994) reported that several alternative routes of IAA synthesis in plants starting from amino acids.

From the abovementioned results, it is clear that treatment No. 4 (amino acids at $0.5 \%+$ micro elements at $0.25 \%$ ) was the most effective one comparing with the other treatments, since this treatment gave the best results concerning plant height, branches number, leaves number, also it increased plant diameter and leaves area comparing with the control.

\section{REFERENCES}

Cottenie, A.; M. Verloo; L. Kiekens; G. Velgle and R. amerlynuck, (1982). Chemical Analysis of Plant and
Soil, 43- 51. Laboratory of Analytical and Agroch. State Univ. of Belgium, Gent.

Davies, D.D., (1982). Physiological aspects of protein turnover. Encycl. Plant Physiol. New Series, 14 A (Nucleic acids and proteins: structure, biochemistry and physiology of proteins, Eds., Boulter, D. and B Partier, Springer Verlag, Berlin, Heidelberg \& New York, pp: 190-228.

Duncan, D.B., (1955): Multiple range and multiple "F" tests. Biometrics, 11: 1-42.

Garcia J.K.; J. Linan; R. Sarmiento; A. Troncoso, (1999). Effects of different $\mathrm{N}$ forms and concentrations on olive seedlings growth. Acta Hort. 474: 323-327.

Ghanta, P.K. and S.K. Mitra, (1993). Effect of micronutrients on growth, flowering, leaf nutrient content and yield of banana cv., Giant cavandishii. Crop Research. 2: 284-287.

Hashimoto, T. and Y. Yamada, (1994). Alkaloid biogenesis: Molecular Aspects. Ann. Rev. Plant Physiol. Plant Mol. Biol., pp: 245-257.

Laure J.H. and R.S. Johnson, (1989). Peaches, plums and nectarines growing and handling for fresh market. Copyright the Regent of the Univ. of Calif. Division of Agric. and Natural Resources Pub. 331: 74-81.

Nijjar, G.S., (1985). Nutrition of fruit trees. Kalyani Publishers New Delhi, pp. 50-100, India.

Waller, G.R. and E.K. Nowaki, (1978). Alkaliod, Biology and Metabolism in Plants. Plenum Press, New York, pp: 85-247.

Westwood, M.N., (1993). Temperate-zone pomology physiology and culture. Third edition. Himber press, Portland, Oregon, P. 523. 